\title{
Leptin levels in non-obese and obese children and young adults with type 1 diabetes mellitus
}

\author{
Alberto Verrotti, Fania Basciani, Guido Morgese ${ }^{1}$ and Francesco Chiarelli \\ Department of Pediatrics, University of Chieti, Chieti, Italy and ${ }^{1}$ Department of Pediatrics, University of Siena, Siena, Italy \\ (Correspondence should be addressed to A Verrotti, Department of Pediatrics, University of Chieti, Ospedale Policlinico Colle Dell' Ara, \\ Via Vestini 5, 66100 Chieti, Italy)
}

\begin{abstract}
Objective: To evaluate serum leptin levels in children and young adults with type 1 (insulin-dependent) diabetes mellitus and to investigate whether they are different in prepuberty, puberty and young adulthood.

Design: Three groups of diabetics (prepubertal, pubertal and young adults) subdivided into obese and non-obese were studied. Three groups of healthy subjects matched for sex, age and body mass index served as controls.

Results: Diabetic patients had serum leptin concentrations similar to those of controls in all three groups. A small non-significant increase in leptin from the prepubertal to the young adult age group for both diabetics and controls was found. A significant association of serum leptin level with body mass index $(P<0.001)$, female sex $(P<0.001)$ and age $(P<0.01)$ in both the diabetic and control group was present. Insulin-dependent diabetes was not associated with higher leptin concentration.

Conclusions: Serum leptin concentrations are similar in diabetic patients and healthy controls. The association between obesity and leptin concentration was similar in the diabetic and non-diabetic subjects. Type 1 diabetes mellitus does not modify serum leptin concentration.
\end{abstract}

European Journal of Endocrinology 139 49-53

\section{Introduction}

Identification of the obese gene and its protein product, leptin, has increased our understanding of the pathophysiology of obesity $(1,2)$. Recently, it has been demonstrated that changes in blood glucose precede changes in body weight, suggesting that leptin may have a direct effect on insulin action (3). Furthermore, insulin may also have a direct effect on leptin production.

Studies performed in whole rats and in primary rat adipocytes demonstrate that insulin directly regulates $o b$ gene expression (4). These data suggest that there are several relevant interactions between insulin and leptin. In fact, serum leptin concentrations in humans are positively associated with body fat percentage, body mass index (BMI) and serum insulin concentration (5-8). Moreover, recently, Tuominen et al. (5) demonstrated that leptin levels are were higher in subjects with insulin-dependent diabetes mellitus (IDDM) and remained unchanged during hyperinsulinemia in a 240 min euglycemic-hyperinsulinemic clamp.

In spite of many studies (5-8) on serum leptin levels in non-obese and obese subjects, very few studies on adult diabetic patients $(5,9-11)$ have been reported and only one on diabetic children (12). In the present study, we measured leptin levels in a group of non-obese and obese diabetic adolescents and young adults; the aims of the study were: (1) to compare the leptin levels of diabetic patients with those of sex-, age- and BMImatched healthy (non-obese and obese) controls; (2) to determine if leptin levels in diabetics are different in prepuberty, puberty and young adulthood.

\section{Subjects and methods}

Three groups of children, adolescents and young adults with type 1 diabetes mellitus (IDDM), who were carefully matched on the basis of BMI, pubertal stage, duration of disease, metabolic control and insulin requirement, participated in the study. Three groups of healthy children, adolescents and young adults without any metabolic and endocrine diseases served as controls. The pertinent data of the three groups of diabetics and controls are shown in Table 1.

All groups (prepubertal, pubertal and young adults) were subdivided into two subgroups: obese and nonobese.

Tanner stages of the pubertal subjects were as follows: diabetics: non-obese, Stage $\mathrm{II}=3 / 3 \quad(\mathrm{M} / \mathrm{F})$, 


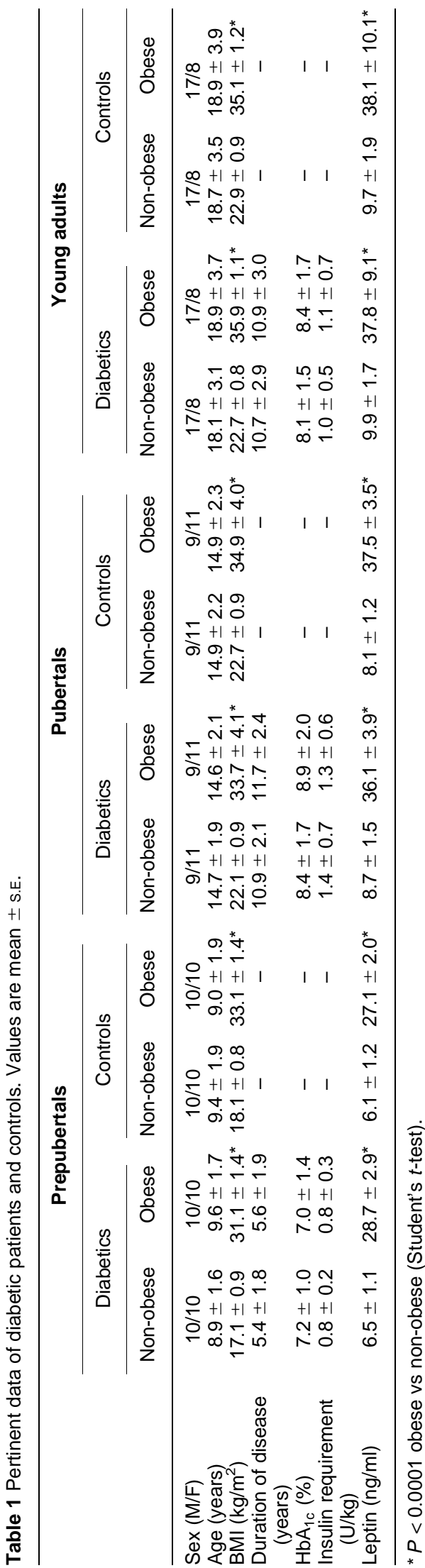

Stage III $=3 / 4$; Stage IV $=3 / 4$; obese, Stage II $=3 / 3$, Stage III $=3 / 4$; Stage IV $=3 / 4$. The controls (non-obese and obese) were strictly matched for Tanner stage.

We studied only diabetic children who were receiving human insulin and followed a multiple daily injection regimen (three or four injections per day). Patients treated by three injections were instructed in the use of two injections of regular insulin via a pen injector 15 min before breakfast and lunch, plus one injection of a mixture of regular and long-acting insulin via a syringe $15 \mathrm{~min}$ before dinner (at $2000 \mathrm{~h}$ ). The insulin dose distribution was $25 \%$ before breakfast, $20 \%$ before lunch and 55\% before dinner (25\% regular and 30\% long-acting insulin). Patients treated by four injections received three injections of regular insulin plus the fourth of long-acting insulin at $2200 \mathrm{~h}$. All patients followed an intensive insulin regimen, as suggested by the DCCT (13).

A detailed medical and nutritional history was obtained from each subject, and the food intake of all children studied was analysed by the recall method.

Height and weight were measured while the subjects were fasting and wearing only their undergarments. BMI or the Quetelet index was then calculated as weight $(\mathrm{kg})$ divided by height ${ }^{2}\left(\mathrm{~m}^{2}\right)$, and this was used as an indirect measure of adiposity.

All obese children had a BMI 95th percentile specific for age and sex. Data on the onset of excessive weight gain were obtained from growth curve charts provided by their pediatricians. All children were in good health, taking no medications, and the obese children were not following a weight control program. The Tanner stage of pubic hair, breast or genital development was assessed by physical examination before participation in the study, according to the Tanner classification (14).

Informed consent was obtained from the parents of all children studied, and the study was approved by the ethics committee of the University of Chieti.

Serum leptin levels were measured after an overnight fast, between 07.30 and $08.00 \mathrm{~h}$, before the first insulin administration of the morning; when blood samples were taken, plasma glucose was determined by a glucose oxidase method (Beckman Instruments, Fullerton, CA, USA): serum glucose levels ranged from 4.9 to $6.5 \mathrm{mmol} / \mathrm{l}$. Serum samples for leptin determination were stored at $-70^{\circ} \mathrm{C}$ for an average duration of 5 months and then evaluated in duplicate using a double-antibody RIA (Human Leptin RIA Kit, Linko Research, St Charles, MO, USA), using a polyclonal antibody raised in rabbits against highly purified recombinant human leptin. The limit of sensitivity for the human leptin assay was $0.5 \mathrm{ng} / \mathrm{ml}$, the intra-assay standard coefficient of variation was $10.6 \%$ and the interassay coefficient of variation was $6 \%$.

Glycosylated hemoglobin $\left(\mathrm{HbA}_{1 \mathrm{c}}\right)$ was measured by HPLC (Bio-Rad Laboratories, Richmond, CA, USA).

All data are presented as means \pm s.E. To compare results of different groups, we used ANOVA (Prophet 
Table 2 Correlation analysis between serum leptin levels and the main parameters of the diabetics and controls as a whole.

\begin{tabular}{|c|c|c|c|c|}
\hline & \multicolumn{2}{|c|}{ Controls } & \multicolumn{2}{|c|}{ Diabetics } \\
\hline & $r$ & $P$ & $r$ & $P$ \\
\hline Male sex & 0.07 & $>0.05$ & 0.11 & $>0.05$ \\
\hline Female sex & 0.40 & $<0.001$ & 0.43 & $<0.001$ \\
\hline Age (years) & 0.31 & $<0.01$ & 0.32 & $<0.01$ \\
\hline BMI $\left(\mathrm{kg} / \mathrm{m}^{2}\right)$ & 0.39 & $<0.001$ & 0.43 & $<0.001$ \\
\hline Serum glucose $(\mathrm{mmol} / \mathrm{l})$ & 0.10 & $>0.05$ & 0.12 & $>0.05$ \\
\hline Insulin dose (U/kg per day) & - & - & 0.09 & $>0.05$ \\
\hline Duration of diabetes (years) & - & - & 0.08 & $>0.05$ \\
\hline $\mathrm{HbA}_{1 \mathrm{c}}(\%)$ & - & - & 0.17 & $>0.05$ \\
\hline
\end{tabular}

Statistical Package, BBN Software). Single within-group comparisons were made by a two-tailed unpaired Student's $t$-test. Multiple stepwise regression analysis was used to identify factors exerting independent influences on serum leptin concentrations. Tests were considered significant if a $P$ value of 0.05 or less was found.

\section{Results}

In the three age groups of subjects studied, diabetic patients showed no significant differences in leptin concentration from the non-diabetic control group matched for age, sex and BMI (Table 1). A nonsignificant increase in leptin concentration from prepuberty to young adulthood was observed in both diabetics and controls (obese and normal weight); this increase was more evident in girls.

When we evaluated serum leptin levels in diabetics and controls as a whole and compared male and female subjects (non-obese and obese), females had significantly $(P<0.001)$ higher leptin concentrations than males, in both groups. The correlation between BMI and leptin concentration was similar in each group $(P<0.001)$.

In both diabetic and non-diabetic subjects a multiple regression analysis of the total study sample with serum leptin as a dependent variable demonstrated significant associations with female sex, BMI and age, while no correlation was found for the insulin dose per kg body weight, duration of diabetes or $\mathrm{HbA}_{1 \mathrm{c}}$ (in diabetics). However, the association of leptin concentration with age was due to the age dependency of BMI. The correlations between serum leptin level and the main parameters of the diabetics and controls are shown in Table 2.

\section{Discussion}

This is the first study to analyse plasma leptin levels in diabetic children and young adults (non-obese and obese). It shows that diabetic children with good metabolic control have similar plasma leptin levels to those of the control population, and there are no differences from the controls in both the prepubertal and pubertal periods. We found no significant correlation between blood glucose level in either controls or diabetics (obese and non-obese). This suggests that variations in blood glucose are not an active signal for leptin secretion, in agreement with other physiological studies $(11,12,15)$.

The study also shows that increased leptin levels are a feature of juvenile obesity in both diabetic children and young adults: the association between obesity (as measured by BMI) and leptin concentration was similar in diabetic and non-diabetic subjects. The relationship between serum leptin and BMI in our obese subjects is similar to that observed in adults with stable obesity $(4,7,15-20)$. In agreement with other reports $(5,9-11)$, our study shows that leptin concentrations in diabetic patients are similar to those in non-diabetic subjects. On the other hand, Tuominen et al. (5) found fasting plasma leptin levels to be higher in patients with IDDM than in controls. These authors suggest that this difference may be due to chronically high insulin concentrations in diabetic patients; it must be remembered that the duration of the disease in these patients was longer than that of our diabetics and this may help to explain the difference between our data and those of Tuominen et al. (5).

Some authors have shown an inverse correlation of leptin level with Tanner stage, independent of body fat $(19,21)$. Our data show a slight increase in leptin level during puberty. Although this increase did not reach statistical significance, these data are in agreement with recent observations $(9,12)$.

Our study shows that both prepubertal and pubertal obese children have higher leptin levels than nonobese diabetic controls. The differences in leptin concentrations are similar in diabetic and non-diabetic subjects. These data are in agreement with previous reports demonstrating hyperleptinemia in obese people $(12,14,22)$. We also confirmed in children the correlation between leptin level and BMI, female sex and age, as reported for adult non-obese populations $(1,6,7)$. Although there was a large overlap in the range of serum leptin concentrations between boys and girls, the mean values for the whole group of males was significantly lower than for the females, in diabetics and in controls. In agreement with recent observations, we suggest that the gender differences in serum leptin concentrations, previously described in adult $(15,23$, 24) and pediatric (12) healthy subjects, is already evident in young patients with IDDM.

In the present study, obese female adolescents with diabetes mellitus exhibited higher serum leptin concentrations than boys despite comparable BMIs as a relative measure of obesity. This is in agreement with recent studies in healthy children and in adults with and without type 2 diabetes $(9,16)$. 
It is important to underline that metabolic control of our diabetic patients was quite stable and satisfactory; in fact, they were followed carefully at the Center for Childhood Diabetes every 2 months after intensive insulin treatment, and we aimed to reach the best possible $\mathrm{HbA}_{1 \mathrm{c}}$ levels as recommended by the DCCT study (13). This could explain the lack of difference between diabetics and control subjects. In accordance with this hypothesis, it is well known that, in diabetic patients with poor metabolic control, abnormalities of thyroid hormones, growth hormone, sex steroids, growth hormone-binding proteins and other parameters are frequently detected (25-29); in contrast, in diabetic patients with improved metabolic control, normalization of the above abnormalities is generally obtained (30-33). It is possible that in diabetic children (obese and non-obese) with poor metabolic control significant differences in leptin concentrations could have been found.

The elevated leptin levels found in both obese children and adult subjects may suggest a decreased sensitivity to leptin, as reported in the $d b / d b$ rodent model of obesity (3). Alternatively, the high leptin levels may simply reflect the enlarged adipose tissue mass.

Our data demonstrate that diabetes mellitus does not affect leptin levels. In fact, we did not find any significant correlation between daily insulin dose and leptin concentrations. This lack of correlation, which is in agreement with the results of other studies carried out in adults with $\operatorname{IDDM}(5,24)$, may be due to different mechanisms. Although insulin has been shown to have an acute stimulatory effect on serum leptin concentration in both rats (4) and patients with non-insulindependent diabetes (9) and a pronounced effect on the regulation of the $o b$ gene in adipose cells (34), serum leptin levels did not appear to depend on the amount of exogenous insulin substitution. Moreover, although it has been suggested that insulin could have a direct effect on leptin production and/or leptin expression (33), studies performed in whole rats and in primary rat adipocytes have not always demonstrated a clear insulin effect on $o b$ gene expression in streptozotocindiabetic rats $(8,35)$. It has recently been documented that euglycemic clamp with steady-state hyperinsulinemia from 80 to $1200 \mu \mathrm{U} / \mathrm{ml}$ maintained for up to $5 \mathrm{~h}$ did not increase serum leptin (8). Accordingly, in humans, postprandial changes in insulin secretion are not accompanied by parallel changes in leptin levels, although the latter show a definite nocturnal rise in lean, obese and diabetic subjects $(10,22,36)$. Moreover, in the study of Muscelli et al. (36), the acute administration of insulin in physiological amounts and under euglycemic conditions did not change circulating leptin levels in lean or obese subjects. Also the data of Larsson et al. (20) confirm that it is unlikely that insulin increases plasma leptin, even at high circulating levels. More recently, Tuominen et al. (5) carried out an interesting study on the effect of a $4 \mathrm{~h}$ euglycemic-hyperinsulinemic clamp in 15 men with IDDM and demonstrated that the fasting plasma leptin levels were higher than controls and remained unchanged during hyperinsulinemia; these authors suggest that patients with IDDM are resistant to insulin action on leptin synthesis. We cannot add our data about this because the aim of our study was to evaluate only the leptin levels in diabetic children who received therapeutic doses of insulin, but our lack of correlation between leptin levels and insulin daily dosage are in partial agreement with these reports. Finally, it is important to remember that there is no strict correlation between insulin dose and plasma insulin levels in diabetic children, because many different factors contribute to the modification of the plasma levels (route of administration, variability in absorption, kinetics of circulation, etc.) (37).

In conclusion, IDDM in non-obese patients with satisfactory metabolic control seems to be associated with normal serum leptin concentrations; obese subjects with IDDM show high leptin levels similar to those of obese healthy subjects. In diabetic children and young adults the concentrations of leptin are similar to those of the non-diabetic population.

\section{Acknowledgements}

We thank Dr T Danne for his invaluable help.

\section{References}

1 Caprio S, Tamborlane WV, Silver D, Robinson C, Leibel R, McCarthy S et al. Hyperleptinemia: an early sign of juvenile obesity. Relations to body fat depots and insulin concentrations. American Journal of Physiology 1996271 626-630.

2 Considine RV, Sinha MK. Heiman ML, Kriauciunas A. Stephens TW, Nyce MR et al. Serum immunoreactive leptin concentration in normal weight and obese humans. New England Journal of Medicine $1996334292-295$.

3 Pelleymounter MA, Cullen MJ, Baker MB, Hecht R, Winters D, Boone T. Effects of the obese gene product on body weight regulation in ob/ob mice. Science 1995269 540-543.

4 Saladin R, DeVos P, Guerro-Millo M, Leturque A, Girard J, Staels B et al. Transient increase in obese gene expression after food intake or insulin administration. Nature 1995377 527-529.

5 Tuominen A, Ebeling P, Stenman U, Heiman ML, Stephens TW \& Koivisto VA. Leptin synthesis is resistant to acute effects of insulin in insulin-dependent diabetes mellitus patients. Journal of Clinical Endocrinology and Metabolism 199782 381-382.

6 Segal KR, Landt M \& Klein S. Relationship between insulin sensitivity and plasma leptin concentration in lean and obese men. Diabetes 199645 988-991.

7 Dagogo-Jack S, Fanelli C, Paramore D, Brothers J \& Landt M. Plasma leptin and insulin relationship in obese and non obese humans. Diabetes 199645 695-698.

8 Kolaczynski JW, Nyce MR, Considine RV, Boden G, Nolan JJ, Henry $\mathrm{R}$ et al. Acute and chronic effects of insulin on leptin production in humans. Studies in vivo and in vitro. Diabetes 199645 699-701.

9 Malmstrom R, Taskinen M-R, Karonen S-L \& Yki-Jarvinen H. Insulin increases plasma leptin concentration in normal subjects and patients with NIDDM. Diabetologia 199639 993-996.

10 Sinha MK, Ohannesian JP, Heiman ML, Kriauciunas A, Stephens TW, Magosin S et al. Nocturnal rise of leptin in lean, obese, and 
non-insulin-dependent diabetes mellitus subjects. Journal of Clinical Investigation 199697 1344-1347.

11 Haffner SM, Stern MP, Miettinen H, Wei M \& Gingerich RL 1996 Leptin concentrations in diabetic and non diabetic MexicanAmericans. Diabetes $199645822-824$.

12 Lahlou N, Landais P, De Boissieu D \& Bougneres PF. Circulating leptin in normal children and during the dynamic phase of juvenile obesity. Relation to body fatness, energy metabolism, caloric intake, and sexual dimorphism. Diabetes 199746 989-993.

13 The Diabetes Control Complication Trial (DCCT) research group. The effect of intensive treatment of diabetes on the development and progression of long-term complications in IDDM. New England Journal of Medicine 1993329977.

14 Tanner JM. Growth and Adolescence. Oxford: Blackwell, 1962.

15 Zimmet P, Hodge A, Nicolson M, Staten M, de Courten M, Moore J et al. Serum leptin concentration, obesity, and insulin resistance in Western Samoans: cross sectional study. British Medical Journal $1996313965-969$.

16 Halaas JL, Gajiwala KS, Maffei M, Cohen SL, Chait BT, Rabinowitz D et al. Weight-reducing effects of the plasma protein encoded by the obese gene. Science 1995269 543-546.

17 Schwarz MW, Baskin DG, Bukowski TR, Kujper JL, Foster D, Lasser $\mathrm{G}$ et al. Specificity of leptin action on elevated blood glucose levels and hypothalamic neuropeptide $\mathrm{Y}$ gene expression in $o b / o b$ mice. Diabetes 199645 531-535.

18 Weigle DS, Bukowski TR, Foster DC, Holdermans S, Kramer JM, Lasser $\mathrm{G}$ et al. Recombinant ob protein reduces feeding and body weight in the $o b / o b$ mice. Journal of Clinical Investigation 199696 2065-2070.

19 Considine RV. Leptin and obesity in humans. Eating and Weight Disorders $1997261-66$.

20 Larsson H, Elmstahol S \& Ahren B. Plasma leptin levels correlate to islet function independently of body fat in postmenopausal women. Diabetes $1996451580-1584$.

21 Ellis KJ \& Nicolson M. Leptin levels and body fatness in children: effect on gender, ethnicity, and sexual development. Pediatric Research 199742 484-488.

22 Maffei M, Halaas J, Ravussin E, Pratley RE, Lee GH, Zhang Y et al. Leptin levels in human and rodent: measurement of plasma leptin and ob RNA in obese and and weight reduced subjects. Nature Medicine 19951 1155-1161.

23 Hodge AM, Dowse GK, Toelupe P, Collins VR, Imo T \& Zimmet PZ. Dramatic increases in the prevalence of obesity in Western Samoa over the 13 year period 1978-1991. International Journal of Obesity $199418419-429$.

24 Danne T, Gruters A, Wladimirova A, Weber B, Horn R, Mayr B et al. Gender-specific differences of serum leptin in obese and normal-weight adolescents: studies in type 1 diabetes and Turner syndrome. Hormone Research 199748 103-107.
25 Adcock CJ, Perry LA, Lindsell AM, Taylor AM, Holly JM, Jones J et al. Menstrual irregularities are more common in adolescents with type 1 diabetes: association with poor glycemic control and weight gain. Diabetic Medicine 199411 465-470.

26 Dunaif A \& Graf M. Insulin administration alters gonadal steroid metabolism independent of changes in gonadotropin secretion in insulin-resistant women with the polycystic ovarian syndrome. Journal of Clinical Investigation 198983 23-29.

27 Sharp SC \& Diamond NP. Sex steroid and diabetes. Diabetes Review $19931318-342$.

28 Chiarelli F, Tumini S, Verrotti A \& Morgese G. Effects of ketoacidosis and puberty on basal and TRH-stimulated thyroid hormones and TSH in children with diabetes mellitus. Hormone and Metabolic Research 198921 494-496.

29 Tamborlane WV, Sherwin RS \& Koivisto V. Normalization of the growth hormone and catecholamine response to exercise in juvenile-onset diabetic subjects treated with a portable infusion pump. Diabetes 197428 785-788.

30 Tamborlane WV, Hintz RL, Bergman M, Ellis KJ, Sherwin RS, Koivisto $\mathrm{V}$ et al. Insulin-infusion pump treatment of diabetes. Influence of improved metabolic control on plasma somatomedin levels. New England Journal of Medicine 1981305 303-307.

31 Holly JMP, Dunger DB, Edge JA, Smith CP, Chard T, Wass JA et al. Insulin-like growth factor binding protein-1 levels in diabetic adolescents and their relationship to metabolic control. Diabetic Medicine $19907618-623$.

32 Sherman LD, Rogers DG \& Gabbay KH. Pulsatility of luteinizing hormone during puberty is dependent on recent glycemic control. Adolescent and Pediatric Gynecology $1991487-93$.

33 Caro JF, Sinha MK, Kolaczynski JW, Zhang PL \& Considine RV. Leptin: the tale of an obesity gene. Diabetes $1996451455-1462$.

34 Becker DJ, Ongemba LN, Brichard V, Henquin JC \& Brichard SM. Diet- and diabetes-induced changes of ob gene expression in rat adipose tissue. FEBS Letters $1995371324-328$.

35 Frederich RC. Hamann A. Anderson S, Lolmann B, Lowell BB \& Flier JS. Leptin levels reflect body lipid content in mice: evidence for diet-induced resistance to leptin action. Nature Medicine 1995 1 1311-1314.

36 Muscelli E, Camastra S, Masoni A, Baldi S, Sironi AM, Natali A et al. Acute insulin administration does not affect plasma leptin levels in lean or obese subjects. European Journal of Clinical Investigation 199626 940-943.

37 Brunetti P \& Bolli GB. Pharmacokinetics and pharmacodynamics of insulin: relevance to the therapy of diabetes mellitus. Diabetes, Nutrition and Metabolism $19971024-34$.

Received 1 October 1997

Accepted 17 February 1998 